\title{
Erratum to: Platinum-group element distribution in the oxidized Main Sulfide Zone, Great Dyke, Zimbabwe
}

\author{
Marek Locmelis • Frank Melcher • Thomas Oberthür
}

Published online: 2 October 2009

(C) Springer-Verlag 2009

Erratum to: Miner Deposita

DOI 10.1007/s00126-009-0258-y

In the original version of this article unfortunately the first name of Frank Melcher was written incorrectly.

The online version of the original article can be found at http://dx.doi. org/10.1007/s00126-009-0258-y.

M. Locmelis $\cdot$ F. Melcher $(\bowtie) \cdot$ T. Oberthür

Federal Institute for Geosciences and Natural Resources (BGR),

Stilleweg 2,

30655 Hannover, Germany

e-mail: F.Melcher@bgr.de

Present Address:

M. Locmelis

ARC National Key Centre for Geochemical Evolution

and Metallogeny of Continents (GEMOC),

Department of Earth and Planetary Sciences,

Macquarie University,

Sydney, Australia 